\title{
Protection secured to the surgical microscope against drops and aerosols generated during eye surgery in the course of the COVID-19 pandemic
}

\section{Protección fijada al microscopio quirúrgico frente a gotas y aerosoles emitidos en el transcurso de cirugías oculares durante la pandemia COVID-19}

\author{
Manuel Caro-Magdaleno ${ }^{1,2}$, Rafael Moro-del-Moral ${ }^{1,2}$, Antonio M. Garrido-Hermosilla ${ }^{1,2 *}$ and \\ Enrique Rodríguez-de-la-Rúa-Franch ${ }^{1,2}$ \\ ${ }^{1}$ UGC Ophthalmology, Virgen Macarena University Hospital, Seville; ${ }^{2}$ RETICS OftaRed, Carlos III Health Institute, Madrid. Spain
}

\section{Dear Editor:}

COVID-19 (coronavirus disease 2019) poses new challenges in our daily routine. The last published figure of infected health workers - reported on May $18^{\text {th }}$ - was 51,090 in total and 152 new cases that same day ${ }^{1}$. Therefore, we must learn to protect ourselves to continue with our daily surgical routine as close to the pre-existing normality.

The Ministry of Health has published a protocol on reincorporation to scheduled surgical activities. It recommends to perform a double clinical-epidemiological screening (14 days and 72 hours before surgery) and perform PCR (polymerase chain reaction test) on a nasopharyngeal sample within 72 hours before surgery, although it specifies the following: "In alert scenario I, if the epidemiological situation allows it, and in selected low-risk patients and low complexity surgeries, we recommend assessing the omission of nasopharyngeal PCR, while maintaining the rest of the process"2.
The American Academy of Ophthalmology, on May 13,2020 , published some recommendations for ophthalmic surgery during the COVID-19 pandemic, stating that, in phacoemulsification, although there is aerosolization during the ultrasound phase, the aqueous humor has been replaced by viscoelastic, so the risk of aerosolized virus is "extraordinarily low"3.

Even so, there is no "zero risk" from such drops and aerosols on the surgeon's conjunctiva, and it is known that protective goggles hinder visibility during surgery. In addition, the conjunctiva has been recently published as a possible portal of entry for severe acute respiratory syndrome coronavirus type 2 (SARS-CoV-2).

For this reason, we initially started using the "microscope field" Microscope Drape-Zeiss MD® (Premier Guard Intl. Ltd., Hong Kong, China; European reference 10-3134EU, 117 by $267 \mathrm{~cm}$ ), although it made surgical maneuvers extremely difficult, due to its size and the fact that the field had to be lifted several times.
Available online: 09-11-2020 Rev Mex Oftalmol (Eng). 2020;94(6):264-266 www.rmo.com.mx 2604-1731/@ 2020 Sociedad Mexicana de Oftalmología. Published by Permanyer. This is an open access article under the CC BY-NC-ND license (http://creativecommons.org/licenses/by-nc-nd/4.0/). 


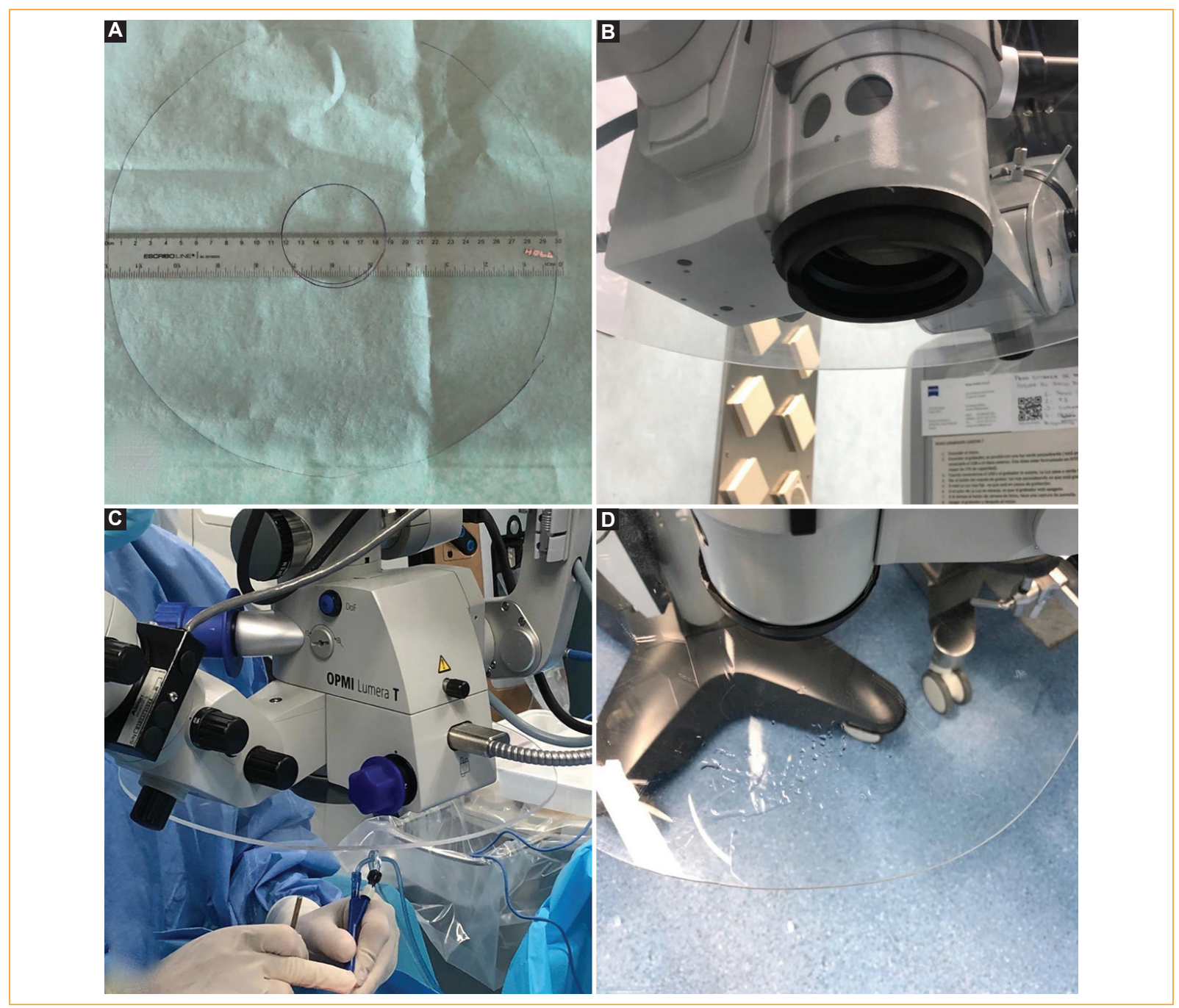

Figure 1. A: 2-mm thick circular protector, with a larger diameter of $30 \mathrm{~cm}$ and a 7-cm central aperture. B: Protector adapted to the microscope with a rubber gasket of the microscope's protective field. C: Protector adapted to the microscope during phacoemulsification. D: Protector after cataract surgery with several drops and condensed aerosols emitted from the eye of the patient during surgery.

As a consequence, Dr. Moro designed a protector that would not make surgery difficult and would contain most of the drops and aerosols emitted. This protector consists of two parts: the first is a circular 2-mm thick methacrylate plate, with a diameter of 30 $\mathrm{cm}$ and a $7 \mathrm{~cm}$ aperture that fits into the microscope with the second piece, a rubber gasket that is used to attach the field for the aforementioned microscope (Fig. 1 A). We have tested its use in Zeiss microscopes, models OPMI Lumera $\mathrm{i}$ and OPMI Lumera $\mathrm{T}$ (Figs. $1 \mathrm{~B}$ and C). We verified that it has not detached during the routine practices of the operating room, and the abundant presence of drops has been confirmed (Fig. 1 D).

For this reason, we believe that this protective element could be used to minimize the possibility of contact with drops and aerosols coming from the patient's eye during ocular surgery, without limiting the range of movements and avoiding inconvenient manipulations of the microscope field.

\section{Conflicts of interest}

The authors declare no conflicts of interest. 


\section{Ethical disclosures}

Protection of human and animal subjects. The authors declare that no experiments were performed on humans or animals for this study.

Confidentiality of data. The authors declare that no patient data appear in this article.

Right to privacy and informed consent. The authors declare that no patient data appear in this article.

\section{References}

1. Redacción médica [Internet]. 21 de mayo de 2020 (Actualizado el 22 de mayo de 2020). Coronavirus: estadística de profesionales sanitarios contagiados en España. Disponible en: https://www.redaccionmedica.com/ secciones/interactivos/coronavirus-medicos-contagiados-sanitarios-5123.

2. Ministerio de Salud, Consumo y Bienestar Social [Internet]; 2020 [actualizado 16 de mayo de 2020; citado 22 de mayo de 2020]. Recomendaciones para la programación de cirugía en condiciones de seguridad durante el periodo de transición de la pandemia covid-19. Disponible en: https:// www.mscbs.gob.es/profesionales/saludPublica/ccayes/alertasActual/ nCov-China/documentos/200517-DOCUMENTO_CIRUGIA-FINAL_(2).pdf

3. American Academy of ophthalmology [Internet]. 13 de mayo de 2020. Special considerations for ophthalmic surgery during the COVID-19 pandemic. Disponible en: https://www.aao.org/headline/special-considerations-ophthalmic-surgery-during-c. 